\title{
On the Cover
}

Portions of the following are based on an interview with the artist on June 25, 2007.

Fourteen years ago, Morris Eaddy had a dream. In his dream, he was walking through a large building that was filled with brightly colored paintings, and somehow he knew that he had painted them. At the time, Eaddy, who was in his late 50s, was not an artist; he was president and CEO of the Lakeview Center in Pensacola, Florida, a large behavioral healthcare program, and only beginning to think about retirement plans. Reflecting upon his dream, he asked himself, "If you are ever going to do this-when?" The image was so vivid and the question so challenging that shortly after his dream, he enrolled in a watercolor painting course at Pensacola Junior College and, concomitant with the ending of his first career, began training for his second.

A native of central Florida, Eaddy earned a $\mathrm{PhD}$ in clinical psychology in 1962 from the University of Florida. That same year, he and his wife Lee moved to Pensacola, where in 1965 he became director of the local mental health clinic, later named the Lakeview Center. Under his stewardship, the center grew to include comprehensive behavioral healthcare services and a staff of 1,800, providing services locally, in other Florida cities, and in other states as well. Eaddy has been nationally recognized for his pioneering work bringing multiple aspects of behavioral and mental health treatment under one administrative and economically efficient roof. He was the founding chairman of the board of Mental Health Corporations of America and the Mental Health Risk Retention Group. In addition, he was three times president of the Florida Council for Community Mental Health and treasurer of the National Council for Community Mental Health.

Eaddy was the youngest and the only boy in a family of four. Eaddy said that as a child he did "art" because his sister Bess gave him colored pencils that fascinated him. He liked to draw cartoons and animals, but he had no formal training until recently. In his planning for retirement, he knew he wanted to unplug from his life as a CEO because as satisfying as it was, he wanted to move into something totally different. He said that much of what he did as a CEO was because he had to, but his art is different. He does it because he wants to. It has transformed his life, which was his goal in retirement.

In addition to the community art courses, Eaddy began taking workshops from nationally recognized artists in other states. He purchased books and videos on art instruction and learned by watching master artists as well as by doing. After a while, he found that all his evenings and vacations were spent painting. He credits his early instructors for starting him on the path to becoming an artist and keeping him motivated. Their infectious enthusiasm was the key. The instructors built on his strengths, helped him feel that he was making progress, and gave him the reinforcement he needed at the beginning. "I felt like a kid putting stick figures on the refrigerator. Although I wouldn't frame them now, at the time I thought they were great." He said that while he picked up something from each artist, he worked at developing his own voice or way of expressing himself. At this point, he said, "People are able to recognize my art work at exhibits."

Eaddy considers himself a colorist. In each of his paintings, color stimulates an experience or emotion that resonates with the viewer. His curiosity about people and what they do informs his art. Eaddy feels that many people go into psychology because of a curiosity about human behavior and about themselves. Since he does not have to make a living from his art, he feels free to experiment-and experiment he does. He uses watercolors, acrylics, and oils, has a wide range of subject matter, and paints on a variety of surfaces, from watercolor paper and canvas to Yupo paper (actually a synthetic). He may have as many as 25 paintings at a time in progress. He chooses colors intuitively, and this intuition comes in part from his broad and intense experimentation as well as his creative imagination.

The painting Celebrations, on the cover of this issue, started as an abstract painting. Eaddy was putting the painting together using both repetition in the shapes and contrast in the colors for effect, but he soon recognized that the rectangle just off center would be the focal point of the painting. But it needed something — people_-so he quickly painted in some human figures. He felt the people appeared to be going some place to celebrate, hence the buildings hinted at in the distance and the rays of color and light. The painting won a meritorious award in a local competition.

The award-winning authors in this issue of the American Psychologist are likely to have had dreams that inspired their careers. The American Psychological Association and the American Psychological Foundation have recognized and celebrated their work. It is most fitting that the art on the cover is about celebration and was painted by an award-winning psychologist whose dream transformed him into an artist.

Sandra M. Fowler Art Co-Editor 